UDC 631.151.61:658

DOI: 10.31651/2076-5843-2019-1-102-113

\author{
Dub Bohdana Stanislavivna, \\ PhD Candidate (Economics), \\ The Bohdan Khmelnytskyi National University of \\ Cherkasy \\ Cherkasy, Ukraine \\ ORCID ID: https://orcid.org/0000-0001-8060-1970 \\ b.dub@ukr.net
}

\title{
COMPLEX ASSESSMENT OF UKRAINIAN AGROHOLDINGS' ECONOMIC SECURITY
}

\begin{abstract}
Retrospective diagnostics of main financial results of activity (profit, earnings and yield of shares); business capital, market capitalization, EBITDA, operating margin and net profit margin, $P$ / E, ROA, ROE, $R O C$ as of 2018 and an average of 5 years; Consideration of Montier C-Score and Piotroski F-Score indicators on financial issues of companies; liquidity of the balance of agroholdings on the criterion of the ratio of assets and liabilities; the coefficient analysis of enterprises and the diagnosis of bankruptcy probabilities using models of multiple discriminant analysis (MDA model), logistic regression (Logit-model) and rating methods (Beaver's indicators and definition of the class of the potential beneficiary of the investment prokect) helped to formulate a generalized conclusion on the probability of bankruptcy according to models and a general assessment of the financial condition of agricultural companies.

Based on the analysis, it has been determined that, according to all methods of the agroholding, the sample collectively generates a series from the highest to the lowest: MHP / Kernel, IMC, Agroton and Avangard. In view of this, it is necessary to formulate and continuously improve integrated risk management systems (integrated systems of enterprise economic security), rather than separate procedures at the level of different departments of the company.
\end{abstract}

Key words: agricultural holding's economic security, profit, revenue, profitability, efficiency, EBITDA, liquidity, risk, bankruptcy, insolvency.

Introduction. In the context of providing national security, along with its political and military components, economic and food parts are very important. The agricultural sector of Ukraine, having unique resources, together with the development of innovative information technologies, is able to provide high-quality economic growth of the country. In Ukraine, the largest and most influential representatives of the agricultural sector are agricultural holdings. Therefore, it is necessary to assess the state of economic security of these economic entities.

Literature review. Specifics of enterprises operation in agrarian and industrial complex were examined by V. H. Andriichuk, M. Ya. Demianenko, Ye. M. Kyryliuk and P. T. Sabluk; economic security of agricultural and agro-industrial sector studied N.V. Biloshkurska, V. V. Boyko, K. V. Kovalelenko, L. V. Kudel and M. I. Yaremov.

Determination of general problem unsettled parts. In fact, in this subject area there are a number of problematic issues, among researchers there is no unity of views on a wide range of economic security items, there is a lack of studies on the enterprise economic security system in certain areas (including agricultural), no standard methodology for assessment of business entities economic security, agricultural holdings are practically not considered in the context of economic security. In this regard, the domestic research development adapted to the conditions of modern Ukrainian economy is actualized.

The Purpose of the article is to make comprehensive analysis of Ukrainian agroholdings' economic security in the methodological and theoretical basis framework and practical recommendations justification for Ukrainian agroholdings' economic security improvement and to determine the main directions of these systems innovative development.

Results and discussion. The most popular methods for company's economic security assessing are expert evaluation and integral indicator. It should be noted that the separation of the 
company's economic security into components and calculation of integral index will not be used here on purpose, given their current imperfect methodology. It was also decided not to conduct separate expert opinion polls on the influence factors, etc. due to the too high method subjectivity and the interpretation ambiguity of the economic security concept essence, the agroholdings' role, the situation on agrarian market, land reform, national policy, food threats, etc. The selection of experts itself appears to be a complex process and does not create trust.

The coefficients are used in part to assess financial status and bankruptcy as the most reliable and most important indicators - the biggest problems of agroholdings in recent years were precisely from the financial component of the company's economic security system. External factors are taken into account in the risk database (risk register) as a qualitative method for determining risks. This is explained by the very qualities of external factors - uncertainty, variability, presence of negative, destructive scenarios, etc., where the quantitative assessment is false, approximate and unreliable.

For further analysis, 5 agrocorporations were selected: Avangard, Agroton, IMC, Kernel and MHP. The criteria for selecting companies were geographical representation (activities in different regions of Ukraine) and information accessibility (including financial reporting, reports for investors, data on risk management systems). Three agricultural holding companies based on the land bank size are included simultaneously in the top 35 world largest landowners 2017 ranking: Uklandfarming (Avangard is part of it), Kernel, Myronivskyi Hliboproduct (MHP). In addition, in different ratings of management quality, reputation, etc. these companies are usually leaders.

The information base of all author's calculations was open consolidated financial statements of agricultural companies [1-6], unless otherwise indicated.

1) The general financial and economic state of the agroholdings in the sample will be considered by the indicators of earnings, net profit and yield of shares in 2012-2017. The financial year in agroholdings coincides with the calendar, except for Kernel - it corresponds to marketing cycle (beginning and ending June 30). The data was released by the end of April 2018, and in Kernel - on the 30th of June.

The leaders by revenue amounts (Fig. 1) are Kernel and MHP - 2.4 and 1.3 billion USD. respectively, the lowest in Agroton - 51 million USD. In all companies there was a recession in 2015 (most affected by military actions and changes in the taxation of subsidiaries), but the strongest hit had indicators in Avangard (in 2015, the revenues decreased three times compared with 2012, and then falls, reaching its minimum for the indicated period in 2017 - USD 127.9 million).

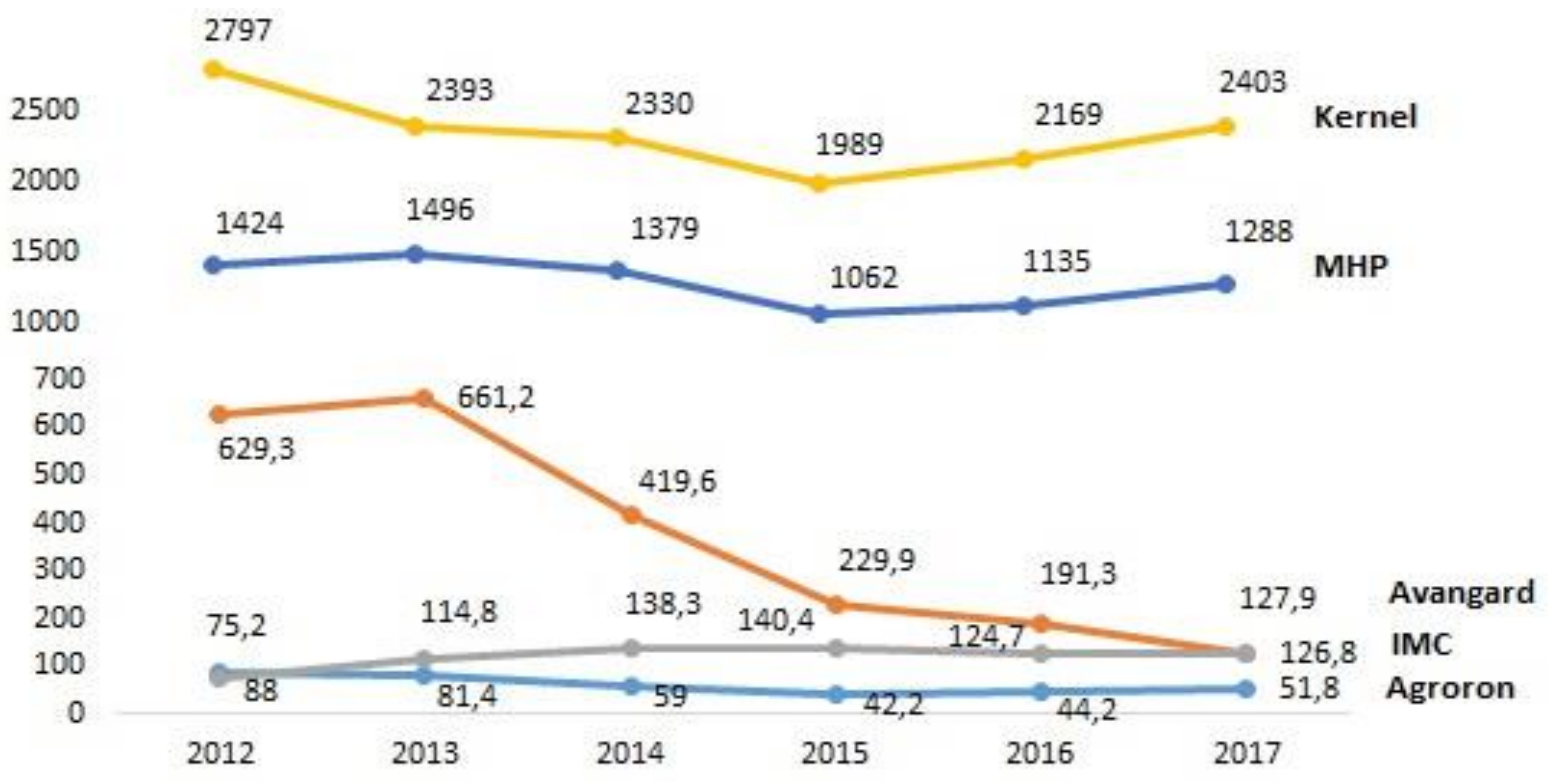

Source: Formed by the author

Fig. 1. Revenue of agroholdings in 2012-2017, USD mln. 
The better financial analysis and presentation of the company's real status is the net profit (or loss) indicator (Fig. 2).

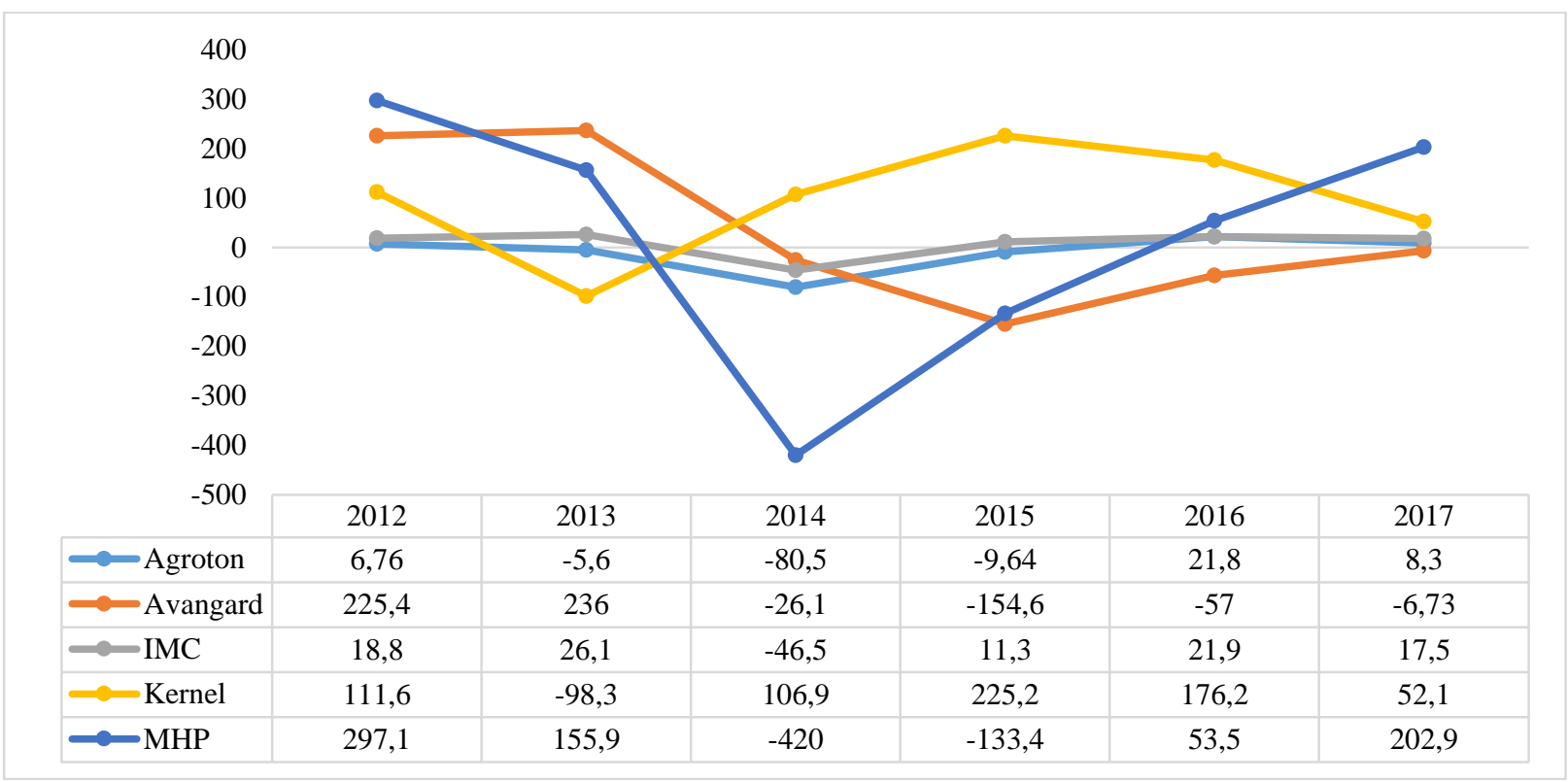

Source: Formed by the author

Fig. 2. Net profit (loss), USD mln.

According to these data, there are separate periods of indicators reduction: for Kernel, this was 2013, 2016 and 2017, with the period of growth in 2014-2015 marketing year; the Avangard's largest decline was in 2015; for MHP, Agroton and IMC - in 2014. According to 2017 financial year, everyone except the Avangard earned a profit for the second consecutive year. Instead, Avangard reached the lowest loss amount (as negotiations were held on debt restructuring). Ivanov N.S. [7] emphasizes that profit is the main indicator of the economic security system efficiency. It as a criterion is also used in most methods of assessing economic security.

The normalized earnings per share is positive only in Kernel and MHP (Fig. 3). For EPS MHP shares are considered a worthwhile investment.

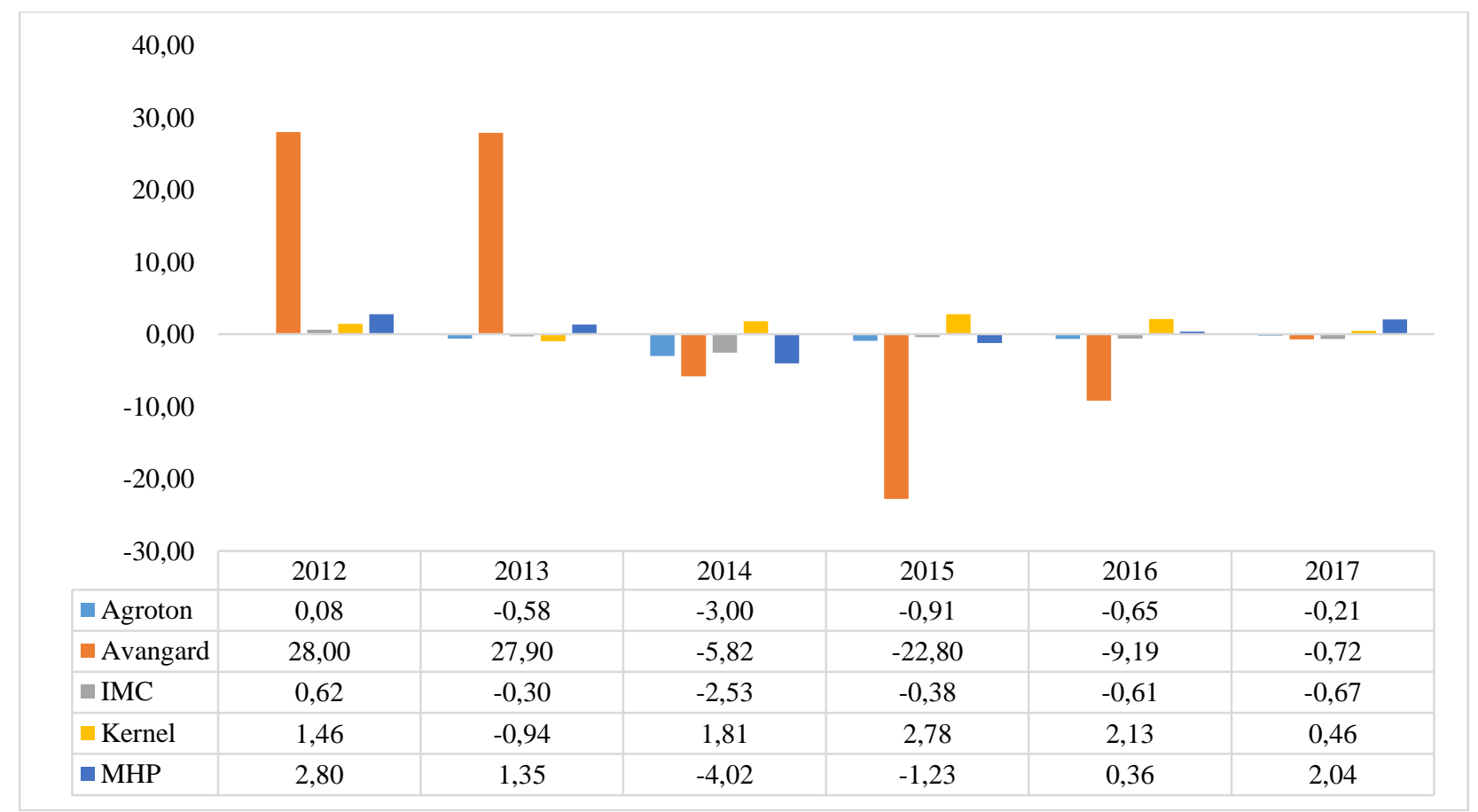

Fig. 3. Normalized EPS (earnings per share)

Source: Formed by the author based on [8] 
2) Financial Indicators

Table 1 summarizes the key financial indicators of agroholdings (21 criteria). Best numbers in each category are highlighted.

Table 1

Key indicators of the efficiency of financial and economic agroholdings' activity

\begin{tabular}{|l|l|l|l|l|l|}
\hline Name & $\begin{array}{l}\text { Agroton } \\
\text { Public }\end{array}$ & $\begin{array}{l}\text { Avangardco } \\
\text { Investments } \\
\text { Public }\end{array}$ & $\begin{array}{l}\text { IMC } \\
\text { SA }\end{array}$ & $\begin{array}{l}\text { Kernel } \\
\text { Holding } \\
\text { SA }\end{array}$ & $\begin{array}{l}\text { MHP } \\
\text { SE }\end{array}$ \\
\hline Enterprise Value, USD million & 10.3 & 279.6 & 184.9 & 1,794 & 2,32 \\
\hline Market capitalization (Mkt Cap), USD million & 20.2 & 17.9 & 126.3 & 1,111 & 1,121 \\
\hline EBITDA & 12.4 & 2.46 & 45.2 & 252.7 & 451.7 \\
\hline EBITDA margin \% & 23.9 & 1.82 & 35.7 & 8.40 & 32.7 \\
\hline EBITDA margin 5-year Avg & 22.1 & 9.93 & 40.9 & 13.1 & 35.5 \\
\hline EV / EBITDA & 0.83 & 113.6 & 4.09 & 7.10 & 5.14 \\
\hline P/E & - & - & - & 16.7 & 6.43 \\
\hline P/E 5-year Avg & - & 2.27 & 6.08 & 18.6 & 3.36 \\
\hline P/E Forecast 2-year & - & 0.25 & 5.58 & 5.42 & 6.07 \\
\hline Net margin \% & 23.2 & -9.38 & 17.4 & 3.49 & 14.9 \\
\hline Net margin \% 5-year Avg & -20.2 & -14.6 & 5.70 & 4.42 & -2.43 \\
\hline ROA (Return on Assets) \% & 12.0 & -2.43 & 10.8 & 4.60 & 8.61 \\
\hline ROA \% 5-year Avg & -6.55 & -3.28 & 4.27 & 6.46 & -0.53 \\
\hline ROC (Return on Capital) \% & 10.1 & -8.09 & 22.8 & 11.3 & 14.3 \\
\hline ROE (Return on Equity) \% & 14.3 & -13.0 & 20.1 & 9.00 & 21.3 \\
\hline ROC \% Greenblatt & 12.6 & -3.55 & 19.5 & 10.9 & 14.9 \\
\hline ROC \% Greenblatt 5-year Avg & 10.7 & 1.94 & 30.4 & 17.5 & 18.8 \\
\hline Operating margin \% & 19.2 & -9.53 & 26.3 & 6.55 & 25.2 \\
\hline Operating margin \% 5-year Avg & 17.3 & 2.70 & 33.4 & 10.3 & 27.3 \\
\hline Montier C-Score & 3.00 & 3.00 & 2.00 & 2.00 & 3.00 \\
\hline Piotroski F-Score & 6 & 6 & 5 & 5 & 5 \\
\hline
\end{tabular}

Note: Avg - average

Source: Formed by the author on the basis of [8]

For greater objectivity in assessment, the company's market value and capitalization are presented simultaneously. The company's market value is the sum of equity capital or market capitalization and liabilities less cash. MHP has the largest value - over USD 2 billion, the lowest is in Agroton; even in the troubled financial period in the Avangard, the value of the company is almost 280 million USD. Maximum of represented market capitalization (the product of stock price on their number in circulation), is again in the MHP, in Kernel it is not much smaller. According to this indicator, Avangard has the minimum value, since it takes into account the price of the stock, which is the smallest lately.

The price / earnings ratio $(\mathrm{P} / \mathrm{E})$ is a widely used financial metric, but it has some disadvantages. It compares the yield of the stock with the current market price and is a well-known indicator of the company's potential for future growth. The indicator is useful for comparing companies in one economic sector. At the same time, the coefficient usually shows how much the market is willing to pay a higher price, compared to revenues in anticipation of the company's future growth (that is why for technology companies this figure is often overestimated [9]). The lower indicator confirms expectations of lower company growth rates or less favorable macroeconomic conditions that could negatively affect the company. But problems arise with an overvalued indicator and overoptimistic expectations or changes in the number of shares by 
management, while the denominator of the coefficient decreases and the total value increases accordingly. On average, P/E is the largest in Kernel for 5 years - 18.6; in 2019 - 16.7; according to the forecast, the largest coefficient in the next 2 years will be in the MHP.

The deficiencies of $\mathrm{P} / \mathrm{E}$ as a financial indicator to some extent could be resolved with the help of EV / EBITDA (the ratio of enterprise value to income before interest, taxes, depreciation and ammortisation). It measures the company's income from capital investment. EBITDA clearly shows the financial results of the company, because it does not take into account liabilities payments, tax payments and accounting procedures. EBITDA is most often used by domestic economic journalists and market analysts to analyze agribusinesses, to form ratings, etc. The EV / EBITDA helps in the comparability of different companies, it rejects differences in taxation, capital structure (in particular borrowing), and accounting procedures. Limitation of EBITDA is also its advantage. Failure to take into account the payments to be made and depreciation usually improves the overall picture; it was wideused during the crash of "dotcoms" to divert attention from the negative net profit values to a high degree of EBITDA. However, from time to time it will be necessary to update the basic means of production and pay interest and taxes, and the indicator does not take into account these capital costs.

The highest among the studied EBITDA indicators is in MHP - 451.7 million USD, on the second place is Kernel with the value of 252.7 million USD; IMC is the third with significantly less than 45.2 million USD. Agroton has 12.4 million USD, and Avangard - 2.46 million USD. according to the results of 2017.

EV / EBITDA in financially healthy firms is at level of 11-14, at the end of 2017 S \& P 500 (500 largest companies in the world) had an average of around 12.75. None of the agrocompanies analyzed corresponds to this criterion. The highest value among the companies represented in the sample is Kernel - 7.1.

The largest margin of net profit in 2018 is in Agroton - 23.2; in Avangard, this value is generally negative at -9.38 . On average, over 5 years the greatest value was in the IMC and the least in Agroton. For profitability of assets in 2017, the highest value was in Agroton - 12, for 5 years the best indicator was in Kernel $-6,46$.

The highest levels in indicators of return on overall and own equity, margin of operating profit is in IMC, the lowest - in Avangard. According to Montier score, none of the companies are suspected of manipulating the reports (according to a scale from 0 to 6: 0 - there are no grounds for doubting the truthfulness of the data, 6 - all the reasons to doubt it). Agroton, Avangard and MHP have ratings of $3, \mathrm{IMC}$ and Kernel -2 .

Piotroski F-Score is a metric of company's financial well-being, which analyzes the trends in the company's reports on profitability, financial leverage, liquidity, funding sources and performance in a 9-point scale. The highest rates are 8 and 9, these firms are significantly higher in growth rates than those with values 1 and 2. The sample companies have relatively high values at 5 (IMC, Kernel, MHP) and 6 (Avangard and Agroton).

Market statistics lets to calculate the $\beta$-coefficient, an important indicator of the securities risk, which reflects the degree of their profitability response to the market yield change (determined by the market index for 60 months). At the beginning of 2019, most companies in the sample have "conservative" stock exchanges (Beta $<1$ ), their securities' are less than the market response rate. "Aggressive" are only Avangard papers (Beta $>1$ ), they have a higher degree of return response to market changes (Table 2).

Table 2

Risk of agroholdings' securities

\begin{tabular}{|l|l|l|l|l|}
\hline Ticker & Name & Market capitalization, mln. USD & Beta & Type \\
\hline AGT & Agroton Public & 20.4 & 0.92 & conservative \\
\hline AVGR & Avangardco Investments Public & 17.9 & 2.99 & aggressive \\
\hline IMC & IMC SA & 127.5 & 0.56 & conservative \\
\hline KER & Kernel Holding SA & 1,101 & 0.48 & conservative \\
\hline MHPC & MHP SE & 1.159 & 0.81 & conservative \\
\hline
\end{tabular}

Source: Formed by the author on the basis of [8] 
Conservative paper has a moderate steady growth, but aggressive ones are more profitable, because they are more risky, and these indicators are interdependent.

3) The liquidity of the balance sheet

The classic method for analyzing the liquidity of the balance sheet is the comparison of assets and liabilities (Table 3 ). The absolute about the liquidity is the ratio A1 $\geq \mathrm{P} 1 ; \mathrm{A} 2 \geq \mathrm{P} 2$; $\mathrm{A} 3 \geq \mathrm{P} 3 ; \mathrm{A} 4 \leq \mathrm{P} 4$.

Table 3

Type of condition of the balance sheet liquidity

\begin{tabular}{|l|l|l|l|l|}
\hline Type & \multicolumn{4}{l|}{ Ratios in balance } \\
\hline Absolute (optimal) & A1 $>$ P1 & A2 $>$ P2 & A3 $>$ P3 & A4 <P4 \\
\hline Normal (admissible) & A1 $<$ 1 & A2 $>$ P2 & A3 $>$ P3 & A4 <P4 \\
\hline Broken (insufficient) & A1 $<$ P1 & A2 $<$ P2 & A3 $>$ P3 & A4> P4 \\
\hline Crisis condition (inadmissible) & A1 $<$ P1 & A2 $<$ 2 & A3 $<$ P3 & A4> P4 \\
\hline
\end{tabular}

Source: Formed by the author

According to the consolidated financial statements, author will formulate estimation table 4 .

The algorithm for determining the liquidity of balance sheet

Table 4

\begin{tabular}{|l|l|l|}
\hline Category & & Balance Sheet (IFRS) \\
\hline highly liquid assets & A1 & Cash and Cash Equiv alents \\
\hline the medium & A2 & Receivables + Other Current Assets \\
\hline low-liquid & A3 & Inventories \\
\hline hardly liquid & A4 & Non-Current Assets \\
\hline $\begin{array}{l}\text { The most urgent } \\
\text { obligations }\end{array}$ & P1 & Accounts Payable \\
\hline $\begin{array}{l}\text { Short-term liabilities } \\
\text { and collateral }\end{array}$ & P2 & Short Term Debt + Other Current Liabilities \\
\hline Long term & P3 & Long Term Debt + Deferred Long Term Liability Charges + Other Liabilities \\
\hline Permanent & P4 & Stockholders' Equity \\
\hline & A1-P1 & \\
\hline & A2-P2 & \\
\hline & A3-P3 & \\
\hline & A4-P4 & \\
\hline & Conclusion \\
\hline
\end{tabular}

Source: Formed by the author

Results for the agroholding Avangard are summarized in Table 5. Only for 2012, the indicators met the second type - allowable liquidity, from 2013 to 2017 the ratio requirements are not fulfilled, the balance is illiquid. According to this method, there are no liquid balances in any agricultural holding of the sample. Only Agroton at the beginning of 2018 formed an absolutely liquid (optimal) balance.

Table 5

Indicators of the balance sheet liquidity of agroholding Avangard, 2012-2017

\begin{tabular}{|l|l|l|l|l|l|l|}
\hline Category & 2012 & 2013 & 2014 & 2015 & 2016 & 2017 \\
\hline A1 & 2.00 & 2.00 & 0.00 & 0.00 & 12.60 & 18.20 \\
\hline A2 & 54.83 & 87.79 & 77.68 & 56.70 & 40.60 & 45.40 \\
\hline A3 & 234.80 & 254 & 144.10 & 71.90 & 69.90 & 72.50 \\
\hline A4 & 968.80 & 1183.80 & 621.70 & 430.40 & 383.50 & 349.90 \\
\hline P1 & 36.20 & 18.20 & 7.09 & 3.38 & 3,06 & 2.30 \\
\hline
\end{tabular}


ISSN 2076-5843 Вісник Черкаського університету. 2019. № 1

\begin{tabular}{|l|l|l|l|l|l|l|}
\hline Category & 2012 & 2013 & 2014 & 2015 & 2016 & 2017 \\
\hline P2 & 5.40 & 14.87 & 32.62 & 2.64 & 43.70 & 120.70 \\
\hline P3 & 204.82 & 263.38 & 82.08 & 298.61 & 343.95 & 73.61 \\
\hline P4 & 1148.80 & 1382.60 & 618.30 & 221.20 & 128.40 & 75.80 \\
\hline A1-P1 & -34.20 & -16.20 & -7.09 & -3.38 & 9.54 & 15.90 \\
\hline A2-P2 & 49.43 & 72.92 & 45.06 & 54.06 & -3.10 & -75.30 \\
\hline A3-P3 & 29.98 & -9.38 & 62.02 & -226.71 & -274.05 & -1.11 \\
\hline A4-P4 & -180.00 & -198.80 & 3.40 & 209.20 & 255.10 & 274.10 \\
\hline & normal (admissible) & $\mathrm{x}$ & $\mathrm{x}$ & $\mathrm{x}$ & $\mathrm{x}$ & $\mathrm{x}$ \\
\hline
\end{tabular}

Source: Formed by the author

4) Coefficient analysis

The indicators of the financial condition for the agholding Avangard are calculated in Table 6. At the beginning of 2018, normative values are not met by most coefficients (11 out of 12), and the turnover of accounts receivable is the largest in sample of all agro-companies (more than 100 days). According to the coefficient analysis, the turning point was 2014 - that year strong indicators turned into a group of stable, and since 2016, most indicators have been in the group of weak companies.

The rest of the holdings have all the indicators of the groups of strong and stable companies, except for Kernel by the margin of operating profit and the coefficient of operating expenses / revenue for 2017. These ratios do not meet normative values and are classified as weak companies.

The inventory turnover time represents the period of sale and replacement of stocks during the reporting period. The shortest period of stock turnover was at Kernel in 2014, indicating an adequate level of industrial security. The largest period was in IMC in 2012 - more than 499 days. Obviously, this is due to the peculiarities of the operating process.

The period of trade payables shows the average time for which the company pays out to its creditors. By the turnover of payables, IMC in 2016 had the lowest figure of 0.81 days, while Avangard in 2017 had the largest - 127.8.

The average payback period for Agroton in 2015 was almost 2 days, the largest in IMC in 2013 - more than 80.

Table 6

Calculation of financial condition indicators (coefficient analysis) of agroholding Avangard, 2012-2017 (according to the methodology of agricultural companies in the USA [10-13])

\begin{tabular}{|l|l|l|l|l|l|l|l|}
\hline No. & Liquidity analysis & 2012 & 2013 & 2014 & 2015 & 2016 & 2017 \\
\hline 1 & Current Ratio & 2.97 & 5.86 & 1.34 & 2.14 & 3.13 & 0.46 \\
\hline & & str & str & s & str & str & W \\
\hline 2 & Working capital (WC) & 404.20 & 526.80 & 106.00 & 103.30 & 99.30 & -191.80 \\
\hline 3 & Working Capital Rule & 1.11 & 1.38 & 0.32 & 0.33 & 0.48 & -1.46 \\
\hline & & str & str & s & s & s & W \\
\hline & Solvency Analysis & & & & & & \\
\hline 4 & Debt / Asset Ratio & 0.27 & 0.24 & 0.40 & 0.65 & 0.76 & 0.85 \\
\hline & & str & str & s & s & W & W \\
\hline 5 & Equity / Asset Ratio & 0.73 & 0.76 & 0.60 & 0.35 & 0.24 & 0.15 \\
\hline & & str & str & s & s & W & W \\
\hline 6 & Debt / Equity Ratio & 0.37 & 0.32 & 0.68 & 1.82 & 3,12 & 5.77 \\
\hline & Profitability analysis & str & str & s & s & W & W \\
\hline 7 & Return on assets (ROA) & 0.17 & 0.15 & 0.08 & -0.14 & -0.03 & -0.01 \\
\hline & & str & str & s & W & W & W \\
\hline
\end{tabular}


Continuation of Table 6

\begin{tabular}{|l|l|l|l|l|l|l|l|}
\hline No. & Liquidity analysis & 2012 & 2013 & 2014 & 2015 & 2016 & 2017 \\
\hline 8 & Return on equity (ROE) & 0.42 & 0.42 & 0.20 & -0.38 & -0.08 & -0.03 \\
\hline 9 & Operating profit margin & 0.37 & 0.37 & -0.03 & -0.67 & -0.30 & -0.07 \\
\hline & Financial History / Performance & str & str & W & W & W & W \\
\hline 10 & Asset turnover & 0.40 & 0.36 & 0.40 & 0.37 & 0.36 & 0.25 \\
\hline 11 & Operating expenses / Revenue & 0.58 & 0.58 & 0.80 & 1.38 & 1.08 & 1.03 \\
\hline & & str & str & s & W & W & W \\
\hline 12 & Depreciation (Expense) Ratio & 0.00 & 0.00 & 0.00 & 0.00 & 0.00 & 0.00 \\
\hline 13 & Interest Expense Ratio & -0.05 & -0.05 & -0.23 & -0.29 & -0.22 & -0.04 \\
\hline & & str & str & str & str & str & str \\
\hline 14 & Net income from operations & 0.42 & 0.42 & 0.20 & -0.38 & -0.08 & -0.03 \\
\hline 15 & Inventory Turn-Days & 212.44 & 212.31 & 164.84 & 123.43 & 143.06 & 193.48 \\
\hline 16 & Accounts Receivable Turn-Days & 31.81 & 48.46 & 67.95 & 88.79 & 76.40 & 127.79 \\
\hline 17 & Average payment period & 32.75 & 15.21 & 8.11 & 5.80 & 6.26 & 6.14 \\
\hline
\end{tabular}

Note: Str stands for a strong company, S - stable, $\mathrm{W}$ - weak

Source: calculated by the author

5) A consolidated assessment of the agroholdings' bankruptcy probability

There are a large number of techniques for calculating the probability of bankruptcy, the risk of insolvency and the financial crisis of companies, identifying weaknesses in financial management by comparing indicators with companies that have already been eliminated. The bestknown and most trusted models are: Springate; Altman [14] (variations: two-factor, Altman and Sabato model of 2007 for the US SME sector, five-factor for companies whose shares have quotations on the stock exchanges, for non-manufacturing companies; for emerging markets), Fulmer [15]; Taffler, Taffler, and Tishow [16], Beaver's figures (by William Beaver 1966, 1968 sometimes considered obsolete, and has an imperfect interpretation, but this model uses classical indicators), Chesser, Lis (Lis R., 1972, UK; in the analysis of post-soviet enterprises shows overestimated values, since does not take into account the impact of taxation and financial activity, only income from sales is considered), the model of Conan and Golder (France, 1979 for medium and small enterprises, of industrial, construction, transport industries), the three-factor model of Legault (Jean Legault, CA-Score, Canada, 1987, has a relatively low probability at $83 \%$ and applies only to industrial firms), method "Credit-men» by J. Depalyan (includes comparison of standards in the industry) and Argenti (A-account; for peer review checklist).

Among the Western financial analysts, the Altman model is the most popular since the late 80 's of the last century. From the latest models, alternative to the Z- method of Altman are the Merton model (1974), Olson score and CHS.

According to Merton's model (Distance to Default, Merton model 1974), KMV (VasicekMerton-Kealhofer) a number of assumptions are proposed, in particular, that dividends are not paid. MHP pays dividends at the moment, therefore, for comparability with the rest of the agroholdings in the sample group this model is not suitable.

The CHS method (probabilistic model Campbell-Hilscher-Szilagy) was developed at Harvard in 2010. Limitation of the model is as folloing: it shows the most realistic results only in the categories where the company already has problems and in comparison with market categories of value and growth its rates are very different from the average. To such group belongs only Avangard, which for several years in a row experienced financial hardship and already declared insolvency. And if there is a permanent loss-making, it is clear that without decisive management 
actions bankruptcy can not be avoided. Therefore, the use of mentioned model in this analysis is also inappropriate.

Among the domestic developments, the most successful are the universal discriminatory model by O. O. Tereshchenko [17] and the model of diagnosing the possibility of bankruptcy by A. V. Matviichuk [18, p. 76-77].

The results of calculation for 16 selected most appropriate models are grouped in Table 7. To previously specified models there added method of the beneficiary selecting of international investment projects developed by the Ministry of Finance in Ukraine and Beneish model for authentication check of the financial statements data (five- and eight-factor).

Table 7

Calculation of the bankruptcy probability for the Kernel holding

\begin{tabular}{|c|c|c|c|c|c|c|}
\hline Model & 2012 & 2013 & 2014 & 2015 & 2016 & 2017 \\
\hline $\begin{array}{l}\text { 5-factor Altman model } \\
\text { for companies whose } \\
\text { shares are quoted on } \\
\text { the stock exchange }\end{array}$ & $\begin{array}{l}\text { Gray } \\
\text { zone }\end{array}$ & Safe & Safe & Safe & Safe & Safe \\
\hline $\begin{array}{l}\text { Modified five-factor } \\
\text { Altman model (for } \\
\text { emerging markets) }\end{array}$ & Safe & Safe & Safe & Safe & Safe & Safe \\
\hline $\begin{array}{l}\text { Altman model for non- } \\
\text { industrial companies }\end{array}$ & Safe & Safe & Safe & Safe & Safe & Safe \\
\hline $\begin{array}{l}\text { The Tuffler-Tishow } \\
\text { Model }\end{array}$ & low & low & low & low & low & low \\
\hline Fulmer Model & low & low & low & low & low & low \\
\hline Springate Model & low & high & low & low & low & low \\
\hline Zmijewsky Model & Bankrupt & Bankrupt & Bankrupt & Bankrupt & Bankrupt & Bankrupt \\
\hline Lis Model & unstable & unstable & unstable & unstable & unstable & unstable \\
\hline Chesser model & excellent & good & excellent & excellent & excellent & excellent \\
\hline Model of Tereshchenko & sanitation & sanitation & sanitation & \begin{tabular}{|l} 
crisis \\
management
\end{tabular} & $\begin{array}{l}\text { crisis } \\
\text { management }\end{array}$ & sanitation \\
\hline Model of Matviichuk & threat & threat & threat & threat & threat & threat \\
\hline $\begin{array}{l}\text { Beaver Model (Beaver } \\
\text { coefficient, normative } \\
\text { value not less than } \\
0,17 \text { ) }\end{array}$ & 0.11 & -0.12 & 0.21 & 0.47 & 0.21 & 0.05 \\
\hline $\begin{array}{l}\text { Beneficiary Choosing } \\
\text { Model }\end{array}$ & $\mathrm{x}$ & class 2 & class 2 & class 1 & class 1 & class 1 \\
\hline $\begin{array}{l}\text { Beneish-M-score } 5 \\
\text { variables }\end{array}$ & $\mathrm{x}$ & satisfactory & manipulates & satisfactory & satisfactory & satisfactory \\
\hline 8 variables & $\mathrm{x}$ & manipulates & manipulates & satisfactory & manipulates & satisfactory \\
\hline Ohlson O-score & $\mathrm{x}$ & $93.59 \%$ & $68.53 \%$ & $86.31 \%$ & $85.69 \%$ & $90.85 \%$ \\
\hline
\end{tabular}

Source: calculated by the author

As in most cases, with the use of several methods for diagnosing the probability of bankruptcy or analysis of the financial situation of domestic enterprises, various, even contradictory, results of calculations have been received. For the agholding Avangard Olson model in 2017 determines the probability of bankruptcy of over 99\%, and a total of 6 models out of 16 confirm the financial problems of the company. However, 6 more models show satisfactory results, 4 models do not give an unambiguous conclusion. The peculiarity of using such a method of diagnostics as the probability of a company's bankruptcy is that it should always be monitored in a 
dynamics of at least 3 years, use several alternative methods and combine with other methods of analysis. In this article, these requirements are met.The main element in assessing the economic security of an agroholding is the continued use of valuations in managerial decisions. Together with all the assessments made, it becomes evident that agholding Avangard needs coordinated actions of crisis managers for the restoration of economic security and a well-established enterprise risk management system.

There are also alarming indicators of financial data manipulation in 2014 in Avangard and 2016 in Agroton (in relation to the latter, such information has already appeared in the media). The MHP indices received a negative interpretation in 2014. The IMC in general fell into this series for two consecutive years in 2015 and 2016, Kernel - for three consecutive years in 2013, 2014, 2016. It should be noted that there is not necessarily because of fraud or error(s) in reports, this is just an additional indicator that the structure the company's income, expenditure or assets is not optimal, does not meet the established standards of successful companies.

For Agroton, 12 models in 2017 show a good financial status, and according to the Olson model, the bankruptcy probability dropped to the lowest level for the analyzed period - of $68.5 \%$ (for comparison: in $2012-94.24 \%, 2015-97.8 \%$ ). But this indicator also makes it necessary to reconsider the existing policies in the company, and it urgently needs to develop comprehensive measures to strengthen the financial and economic situation.

In IMC, too, in 12 models, the probability of bankruptcy is low, but it is important that the Tereshchenko model, which takes into account the economic activity specifics, is the most adapted to domestic conditions, and uses statistical data collected at Ukrainian enterprises, proposes to introduce crisis management. And according to the model of Olson, the risk decreased in 2016, in 2017 again there is a slight increase.

In Kernel, 10 models do not show threats, but both Ukrainian methods - both Tereshchenko and Matviichuk emphasize sanation measures. And the Olson model shows a significant increase in risk.

In MHP, too, 10 models do not reveal any particular problems in financial condition, but Tereshchenko model again identifies the need for crisis management. At the beginning of 2018 the calculation result of the Olson model is the largest for the entire period and the risk increased to $95.26 \%$, on the beneficiary model the class of borrower was also downgraded from first to second. According to the model of Matviichuk, the state is satisfactory. Estimates are contradictory, so we must take into account the mistakes of the second kind - it is better to conduct preventive actions than to miss the critical moment. Proactive program to strengthen the financial situation, development of the company's economic security system became necessary.

The use of discriminant and logistic models for bankruptcy probability in the agroholdings analysis gave in a certain way a systematic vision of the blemishes in the financial component at the company's economic security system. It also takes into account the specifics of the companies activities (comparison of enterprises in one industry), the macroeconomic situation, the work of the enterprise risk management departments and the main indicators of financial and economic activity.

Conclusions and perspectives of further research. Retrospective diagnostics of main financial results of activity (profit, revenue and earnings per share); indicators of enterprise value, market capitalization, EBITDA, operating margin and net earnings, P/E, ROA, ROE, ROC as of 2018 and an average of 5 years; considering of indicators of Montier C-Score and Piotroski F-Score that show companies financial problems; liquidity of agroholdings' balance sheet by asset value to liabilities criterion; ratio analysis and diagnostics of bankruptcy probability using the models of multiple discriminant analysis (MDA-model), logistic regression (Logit-model) and rating methods (Beaver indicators and determining the class of investment project potential beneficiaries) helped to form consolidated conclusion on the bankruptcy likelihood according to models and a general assessment of the financial condition at agricultural companies.

Based on the analysis it was defined that in all the techniques used the agricultural holdings of sample form range from highest to lowest amounts: MHP / Kernel, IMC, Agroton and Avangard. 
Financial problems, according to assessments carried out, are present in all the agricultural companies analyzed. During diagnosis of bankruptcy probability even domestic methods (which usually show the most acceptable results) showed the need for sanation procedures or crisis management. In view of this, it is necessary to formulate and continuously improve integrated risk management systems (integrated economic security systems of the enterprise), rather than separate procedures at the level of different company departments. The development and practical implementation of the innovative development programs of the enterprise economic security system in agroholdings is a prospect for further research.

\section{References}

1. The official website of MHP SE (2019). URL: https://mhp.com.cy/

2. The official website of Avangard (2019). URL: https://avangardco.ua/

3. The official website of Agroton (2019). URL: http://agroton.com.ua/en/

4. The official website of IMC (2019). URL: http://www.imcagro.com.ua/

5. The official website of Kernel (2019). URL: https://www.kernel.ua/

6. The official website of MHP PrJSC (2019). URL: https://www.mhp.com.ua/en/

7. Ivanov, N. S. (2010). Methods in effectiveness assessment of the enterprise economic security system. URL: http://intkonf.org/ivanova-ns-metodi-otsinki-efektivnosti-sistemi-ekonomichnoyi-bezpeki-pidpriemstva/

8. Stockopedia (2019). URL: https://www.stockopedia.com/

9. Investopedia (2019). URL: https://www.investopedia.com

10. BT Understanding Key Ratios (2019). URL: http://farmbiztrainer.com/docs/BT_Under standing_Key_Ratios.pdf

11. Farm Financial Ratios and Benchmarks (2009). URL: https://cdp.wisc.edu/pdf/FarmFinancial Ratios andBenchmarks3192009.pdf

12. Interpreting Farm Financial Ratios (2019). URL: https://www.cottoninc.com/wpcontent/uploads/2015/12/Interpreting_Farm_Financial_Ratios.pdf

13. Key financial ratios (2019). URL: https://grdc.com.au/_data/assets/pdf_file/0016/117322/ 8116-keyfinancial-ratios-fs-pdf.pdf.pdf

14. Altman, E.I. (1968). Financial ratios, discriminant analysis, and the prediction of corporate bancruptcy. The Journal of Finance, 4, pp. 589-609.

15. Fulmer, J.G. Jr., Moon J. E., Gavin T.A., Erwin, M.J. (1984). A Bancruptcy Classification Model for small firms. Journal of Commercial Bank Lending, 7, pp. 25-37.

16. Taffler, R.J., Tisshaw H. (1977). Going, Going, Gone - Four Factors which Predict. Accountancy, 3, pp. 50-54.

17. Tereshchenko, O.O. (2003). Discriminant model for the integrated assessment of the enterprise financial condition. Economy of Ukraine, 8, p. 38-44.

18. Matviichuk, A.V. (2013). Fuzzy, neural network and discriminant models for diagnosing the bankruptcy possibility of enterprises. Neuro-fuzzy simulation technology in economics, 2, p. 71-118.

\section{ДУБ Богдана Станіславівна,}

здобувач наукового ступеня доктора філософії (економічні науки),

Черкаський національний університет імені Богдана Хмельницького, Україна

\section{КОМПЛЕКСНЕ ОЦІНЮВАННЯ СТАНУ ЕКОНОМІЧНОЇ БЕЗПЕКИ АГРОХОЛДИНГІВ УКРАЇНИ}

Проблема. У контексті забезпечення національної безпеки поряд з її політичною та воєнною важливими складовими частинами є економічна та продовольча. Агросектор Украӥни, маючи унікальні ресурси, разом з розвитком інноваційних інформаційних технологій в змозі забезпечити якісне економічне зростання краӥни. В Украӥні найбільшими та найвпливовішими представниками агросектору є аграрні холдинги. Тому необхідним є оцінювання стану економічної безпеки иих економічних суб'єктів. Утім, у цій предметній області є ряд проблемних моментів: серед дослідників відсутня єдність поглядів на широке коло питань економічної безпеки, існує брак досліджень про систему економічної безпеки підприємств конкретних галузей (зокрема аграрної), не сформовано єдиної методики щодо оиінювання стану економічної безпеки суб'єктів господарювання, агрохолдинги практично не вивчаються в контексті економічної безпеки. У зв'язку з иим, 
актуалізується вироблення вітчизняних напраџюювань, прилаштованих до умов сучасної украӥнської економіки.

Мета статmі - здійснити комплексний аналіз економічної безпеки агрохолдингів України у рамках розробки теоретико-методичного базису й обтрунтування практичних рекомендацій щзодо вдосконалення систем економічної безпеки агрохолдингів в Україні та визначення головних напрямів інноваційного розвитку цุих систем.

Методи дослідження. Економічний та фінансовий аналіз, коефіиієнтний метод, методи комплексної оцінки (для оцінювання економічної безпеки та фінансового стану досліджуваних агрокомпаній); табличний та графічний (діаграми) - для візуалізащії результатів дослідження та систематизачії статистичних даних.

Результати. Коефічієнти використано для оцінювання фінансового стану і банкрутства як найнадійніші і найважливіші показники - найбільші проблеми агрохолдингів в останні роки були саме з фінансового складника системи економічної безпеки підприємства. Для подальшого аналізу обрано 5 агрокорпорацій: Авангард, Агротон, ІМК, Кернел, МХП. Критеріями вибору компаній були географічна представленість (діяльність в різних областях Украӥни) та інформаційна доступність (в т.ч. фінансової звітності, звітів для інвесторів, дані про системи ризик-менеджменту). Три агрохолдинги вибірки за розміром земельного банку входять одночасно $і$ до рейтингу топ-35 найбільших латифундистів світу за підсумками 2017 року: Uklandfarming (Авангард входить до його складу), Кернел, Миронівський хлібопродукт. Крім того, за різними рейтингами якості управління, репутаціï $i$ m.n. иі компанії зазвичай є лідерами. Фінансові прорахунки відповідно до проведених оцінок присутні в усіх аналізованих агрокомпаніях, під час діагностики ймовірності банкрутства навіть вітчизняні методи (ще зазвичай показують найприйнятніші результати) показали необхідність санаційних процедур чи антикризового управління.

Наукова новизна. У статті на основі даних фінансової звітності, консолідованої інформації на сайтах фондових бірж тощзо здійснено аналіз фінансового стану 5 агрохолдингів Украӥни. Проведено оцінювання фінансових показників та діагностику стану системи економічної безпеки холдингового підприємства агробізнесу (за МСФЗ та НПСБО) за 5 параметрами: загальний фінансовий стан, основні індикатори, ліквідність балансу, коефіцієнтний аналіз, ймовірність банкрутства.

Висновки. Ретроспективна діагностика основних фінансових результатів діяльності (прибутку, виторгу та дохідності акцій); показників вартості підприємства, ринкової капіталізацї, EBITDA, маржі операчійного та чистого прибутку, P/E, ROA, ROE, ROC станом на 2018 рік та в середньому за 5 років; розгляд індикаторів Montier C-Score ma Piotroski F-Score щуодо фінансових проблем компаній; ліквідності балансу агрохолдингів за критерієм співвідношення активів та пасивів; коефіиієнтний аналіз підприємств та діагностика ймовірності банкрутства 3 використанням моделей множинного дискримінантного аналізу (MDA-моделі), логістичної регресії (Logit-моделі) та рейтингових методик (показники Бівера та визначення класу потенційного бенефіціара інвестиційного проекут) допомогли сформувати узагальнений висновок шзодо ймовірності настання банкрутства згідно моделей $i$ загальну оиінку фінансового стану агрокомпаній. На основі проведеного аналізу визначено, щз за всіма методиками агрохолдинги вибірки загалом формують ряд від найвищих до найнижчих показників: МХП/Кернел, ІМК, Агротон та Авангард. 3 огляду на изе необхідне формування та постійне вдосконалення систем комплексного управління ризиками (інтегрованих систем економічної безпеки підприємства), а не окремі процедури на рівні різних відділів компаніі.

Ключові слова: економічна безпека агрохолдингу, прибуток, виторг, рентабельність, ефективність, ЕВITDA, ліквідність, ризик, банкрутство, неплатоспроможність.

Одержано редакцією: 24.01.2019

Прийнято до публікаиії: 02.02.2019 